\title{
PROSPECTS FOR CREATING A REGIONAL BUDGET AIRLINE IN THE REPUBLIC OF CRIMEA
}

\author{
Vladimir V. Rublev \\ Plekhanov Russian University of Economics, Moscow, Russian Federation \\ Oleg N. Larin \\ Plekhanov Russian University of Economics, Moscow, Russian Federation; \\ Russian University of Transport, Moscow, Russian Federation
}

\begin{abstract}
The 2020 crisis caused by the negative impact of the COVID-19 pandemic had a positive influence on the development of regional air travel. Against the background of an overall drop in passenger traffic exceeding $40 \%$, a number of airports in the Southern Federal District have demonstrated positive development dynamics. With the opening of regular flights to cities in the Southern Federal District and the Republic of Crimea, a number of airports in the Central Federal District and the Volga Federal District by the end of 2020 increased passenger traffic due to the development of the domestic route network. The Russian air passenger market demonstrated high growth and development rates during the period of 2009-2019. The underlying factors of growth and development were the implementation of the subsidizing regional air routes program, the development of competition and the increase in the growth rate of production of the regional jet "SSJ-100". According to the results of activities at the end of 2020, the Russian regional airline (a mono-operator of the "SSJ-100" jet) demonstrated the lowest rate of passenger traffic reduction. The airline also increased its aircraft fleet by 2 units and expanded its regional route network. The Republic of Crimea is a strategically important region of the Russian Federation. Modernization of the regional logistics complex, which includes the development of regular flights to the regions of the Russian Federation, is a priority task of domestic policy. Based on the structural analysis of the air passenger market and the regional logistics system, a model for creating a regional budget airline for the Republic of Crimea is proposed. The result of overcoming the 2008 crisis on the European air passenger market was the strengthening of the role and influence of the budget airlines (increase in market share from 15\% to 50\% from 2009 to 2019). The low-cost air transportation segment of the Russian market demonstrates high potential for development due to growing demand. The development of regional air transportation is one of the key factors in the development of the national aircraft construction system. The results of the study can be used in developing a strategy for the aviation logistics system of the Republic of Crimea, as well as in developing strategies for the development of regional airports on the island and peninsular territories.

Key words: air passenger market, regional air transportation, regional airports, civil aircraft construction, regional economy.
\end{abstract}

Citation. Rublev V.V., Larin O.N. Prospects for Creating a Regional Budget Airline in the Republic of Crimea. Vestnik Volgogradskogo gosudarstvennogo universiteta. Ekonomika [Journal of Volgograd State University. Economics], 2021, vol. 23, no. 2, pp. 57-75. (in Russian). DOI: https://doi.org/10.15688/ek.jvolsu.2021.2.5

\section{ПЕРСПЕКТИВЫ СОЗДАНИЯ РЕГИОНАЛЬНОЙ БЮДЖЕТНОЙ АВИАКОМПАНИИ НА ТЕРРИТОРИИ РЕСПУБЛИКИ КРЫМ}

Владимир Владимирович Рублев

Российский экономический университет им. Г.В. Плеханова, г. Москва, Российская Федерация 


\section{Олег Николаевич Ларин}

Российский экономический университет им. Г.В. Плеханова, г. Москва, Российская Федерация; Российский университет транспорта, г. Москва, Российская Федерация

Аннотация. Кризис 2020 г., обусловленный негативным влиянием пандемии COVID-19, оказал положительное влияние на развитие регионального авиасообщения. На фоне общего падения пассажиропотока, превышающего 40 \%, ряд аэропортов ЮФО продемонстрировали положительную динамику развития. Ряд аэропортов ЦФО и ПФО за счет развития внутренней маршрутной сети увеличили пассажиропоток по итогам 2020 г. за счет открытия регулярного авиасообщения с городами ЮФО и Республикой Крым. Российский рынок пассажирских авиаперевозок демонстрировал высокие темпы роста и развития в период 20092019 годов. Обусловливающими факторами роста и развития послужили: реализация программы субсидирования региональных авианаправлений, развитие конкуренции, увеличение темпов роста производства отечественного лайнера «SSJ-100». По итогам деятельности за 2020 г. российская региональная авиакомпания - моноэксплуатант лайнеров «SSJ-100» продемонстрировала наименьший показатель снижения пассажиропотока, а также увеличила парк воздушных судов на 2 ед. и расширила регионально-маршрутную сеть. Республика Крым является стратегически важным регионом Российской Федерации. Модернизация регионального логистического комплекса, включающего в себя развитие регулярного авиасообщения с регионами РФ, является приоритетной задачей внутренней политики. На основании структурного анализа рынка пассажирских авиаперевозок и региональной логистической системы предложена модель создания региональной бюджетной авиакомпании на территории Республики Крым. Результатом преодоления кризиса 2008 г. на европейском рынке пассажирских авиаперевозок стало усиление роли и влияния бюджетных авиакомпаний (увеличение доли рынка с 15 до 50 \% в период с 2009 по 2019 г.). Сегмент бюджетных авиаперевозок в структуре российского рынка демонстрирует высокий потенциал развития, обусловленный возрастающим спросом. Развитие региональных авиаперевозок является одним из ключевых факторов развития национальной системы самолетостроения. Результаты исследования могут быть применены при разработке стратегии авиатранспортной логистической системы Республики Крым, а также при разработке стратегий развития региональных аэропортов на островных и полуостровных территориях.

Ключевые слова: рынок авиаперевозок, региональные авиаперевозки, региональные аэропорты, гражданское самолетостроение, региональная экономика.

Цитирование. Рублев В. В., Ларин О. Н. Перспективы создания региональной бюджетной авиакомпании на территории Республики Крым // Вестник Волгоградского государственного университета. Экономика. -2021. - Т. 23, № 2. - С. 57-75. - DOI: https://doi.org/10.15688/ek.jvolsu.2021.2.5

\section{Введение}

Присоединение Республики Крым к Российской Федерации стало знаковым геополитическим событием новейшей истории нашего государства. До вхождения территории Крыма в состав РФ (в 2014 г.) доходы регионального бюджета от предприятий индустрии туризма составляли лишь 12,4 \% (по данным за 2013 г.), что свидетельствовало о низком потенциале развития территории. После распада СССР власти Украины уделяли недостаточное внимание развитию инфраструктуры полуострова. Вся транспортная система: аэропорт г. Симферополь, сеть железнодорожного и автомобильного сообщения не соответствовала требованиям туристического рынка, что препятствовало увеличению внутреннего и международного туристического потока. До 2014 г. аэропорт Симферопо- ля имел регулярное авиасообщение только с двумя городами Российской Федерации: Москвой и Санкт-Петербургом, при том, что туристы из России занимали важное место в структуре туристического потока Крыма. Другими возможными направлениями логистики было автомобильное и железнодорожное сообщение через территорию Украины и паромная переправа с территории Краснодарского края. Украинские авиа- и железнодорожные компании были монополистами в структуре логистической системы Крыма. Отсутствие конкуренции и не развитость маршрутной сети аэропорта г. Симферополь с регионами России были ключевыми препятствующими факторами развития туризма на полуострове Крым.

После вхождения Республики Крым в состав Российской Федерации [Федеральный конституционный закон от 21.03.2014 
№ 6-ФКЗ] приоритетным направлением развития Республики Крым стала модернизация региональной транспортной инфраструктуры. Мы отметим лишь самые жизненно важные проекты: 15 мая 2018 г. был введен в эксплуатацию мост, соединивший Республику Крым с Таманским полуостровом (Краснодарский край) [Крымский мост], начато строительство автодороги «Таврида» (2018-2022 гг.). Осуществляется реконструкция крымской железной дороги [Федеральную трассу «Таврида» в Крыму ...].

Ключевой целью модернизации транспортной инфраструктуры Республики Крым является увеличение пропускной способности транспортной системы с целью развития туристического потенциала Республики Крым и рост налоговых отчислений в бюджет региона [Крымская железная дорога ...].

В 2015 г. начались проектные работы по реконструкции Международного аэропорта «Симферополь». Проект включает в себя комплексную модернизацию пассажирского и грузового терминалов, расширение взлетно-посадочной полосы, увеличение количества единовременно базируемых воздушных судов на территории объекта, повышение пропускной способности, с возможностью увеличения годового пассажиропотока до 10 млн пассажиров. Важно подчеркнуть, что проектирование и строительство осуществляют российские инженеры с применением самых современных технологий строительства авиатранспортных комплексов. Планируемая дата завершения строительства - 2023 год. Разработку проекта и контроль на всех этапах строительства осуществляет ФГУП ГПИ и НИИ ГА «Аэропроект» [«Аэропроект»].
Приведем данные пассажиропотока Международного аэропорта «Симферополь» и туристического потока Республики Крым за период с 2014 по 2020 г. (табл. 1).

Следует уточнить, что пассажиропоток аэропорта рассчитывается по принципу совокупного пассажиропотока авиакомпаний, пребывающих и убывающих рейсов. Таким образом, 1 пассажир, совершающий прилет и вылет из аэропорта «Симферополь», составляет 2 ед. в структуре пассажиропотока аэропорта. Для определения роли и влияния авиационного сообщения в структуре пассажиропотока рассматриваемого нами аэропорта рассчитаем процент туристов, пребывающих на территорию Республики Крым авиационным транспортом, в структуре общего туристического потока региона за анализируемый период с 2014 по 2020 г. (см. рис. 1).

В 2014 г., в год вхождения Республики Крым в состав Российской Федерации, доля туристов, пребывающих в Крым авиационным транспортом, составляла 35 \%. Это было обусловлено процессом развития маршрутной сети, разработкой и принятием программы субсидирования региональных авиаперевозок. Данная государственная программа действует на территории РФ с 2015 г., главными задачами которой являются развитие регионального авиасообщения и расширение маршрутной сети региональных аэропортов. Программа доказала свою эффективность как инструмент экономического стимулирования спроса на внутреннем рынке [Рублев, 2020а]. Данная программа предоставляет льготным категориям граждан возможность приобретения авиабилетов по фиксированной цене, стоимость которых ниже рыночной на 20-30 \%.

\section{Пассажиропоток Международного аэропорта «Симферополь» и туристический поток Республики Крым за период с 2014 по 2020 г.}

\begin{tabular}{|c|c|c|}
\hline Год & $\begin{array}{c}\text { Пассажиропоток Международного } \\
\text { аэропорта «Симферополь», млн пасс. }\end{array}$ & $\begin{array}{c}\text { Туристический поток } \\
\text { Республики Крым, млн чел. }\end{array}$ \\
\hline 2014 & 2,8 & 4 \\
\hline 2015 & 5 & 4,59 \\
\hline 2016 & 5,2 & 5,57 \\
\hline 2017 & 5,19 & 5,39 \\
\hline 2018 & 5,14 & 6,8 \\
\hline 2019 & 5,1 & 7,6 \\
\hline 2020 & 4,63 & 6,3 \\
\hline
\end{tabular}

Примечание. Составлено авторами по: [Рублев, 2020а]. 


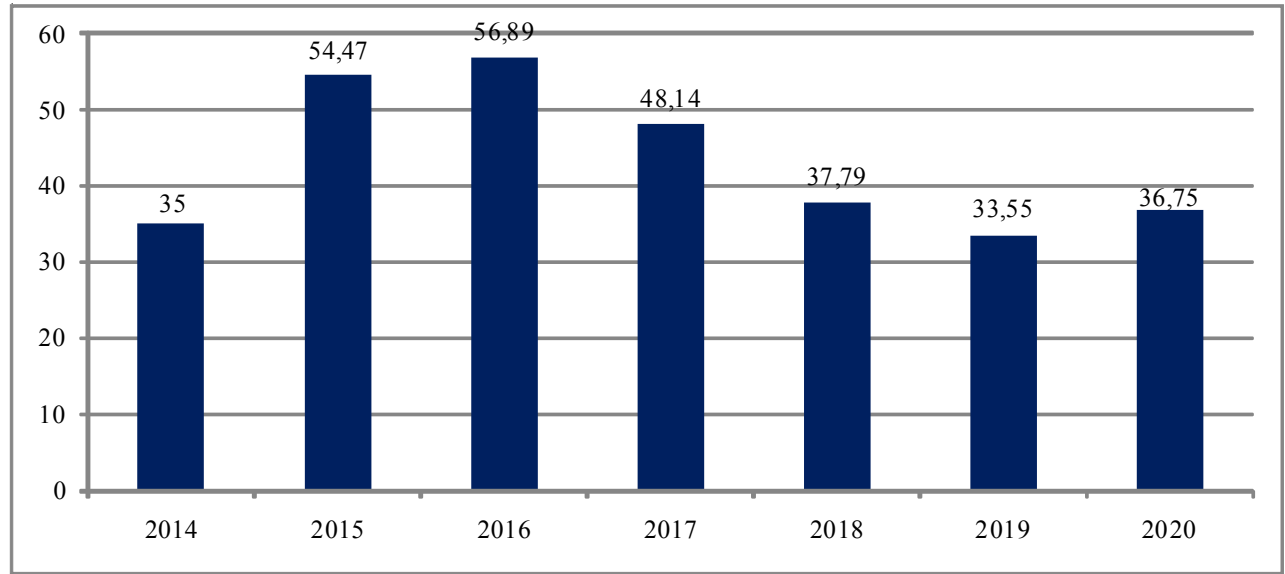

Рис. 1. Доля туристов в структуре общего туристического потока Республики Крым, пребывающих авиационным транспортом, \%

Примечание. Составлено авторами по: [Рублев, 2020а].

Выбывающую разницу компенсирует авиакомпаниям Правительство РФ и региональные органы исполнительной власти. На официальном сайте Федерального агентства воздушного транспорта (Росавиация) приведен список субсидируемых направлений [Федеральное агентство воздушного ....].

Основными пунктами в реализации программы является развитие региональных авиаперевозок на территории РФ, на Дальнем Востоке, в Калининградской области, а также на территории Республики Крым. Необходимо отметить, что перечень субсидируемых направлений ежегодно расширяется. Процесс увеличения количества субсидируемых направлений оказывает положительное влияние на рост пассажиропотока региональных аэропортов и развитие региональных авиакомпаний на территории РФ.

Российская региональная авиакомпания «Азимут» является одним из ключевых участников программы субсидирования региональных авиаперевозок. Авиакомпания была образована в 2017 году. В настоящее время хабом авиакомпании (базовым аэропортом) является аэропорт «Платов» (ЮФО, г. Ростов-на-Дону), и кроме этого, начиная с 2019 г. авиакомпания формирует хаб на базе аэропорта «Пашковский» (ЮФО, г. Краснодар). «Азимут» является эксплуатантом российского регионального узкофюзеляжного среднемагистрального лайнера «SSJ-100». В 2020 г. авиакомпания расширила парк воздушных судов с 11 до 13 ед. [Авиакомпания «Азимут»]. По итогам деятельности за кризисный 2020 г. данный авиаперевозчик получил наименьший показатель падения пассажиропотока (2,1%) (см. табл. 2).

Авиакомпания «Азимут» является классической региональной авиакомпанией, применяющей в маркетинговой стратегии элементы бюджетного авиаперевозчика. Воздушные суда авиакомпании имеют одноклассовую компоновку салона, что позволяет размещать до 103 пассажиров (версия «SSJ-100»; с двухклассовой компоновкой, рассчитана на перевозку 78 пассажиров). В структуре маршрутной сети преобладающее количество составляют рейсы малой и средней протяженности от 500 до 2000 км, что позволяет эффективно эксплуатировать парк воздушных судов.

В период пандемии COVID-19 лайнеры авиакомпании показали рекордный суточный налет, составивший более 9 часов. Таким образом, одно воздушное судно авиакомпании «Азимут» выполняло в сутки до 9 рейсов, что является рекордным результатом для воздушных судов данного класса.

Ключевым фактором укрепления данного авиаперевозчика на рынке является конкурентное преимущество эксплуатации воздушных судов российского производства. Падение пассажиропотока на общем российском рынке, составившее в 2020 г. более $40 \%$, сопровождалось девальвацией национальной валюты. При влиянии этих факторов произошло увеличение долговой нагрузки у значительной части российских авиакомпаний, осуществля- 
B.В. Рублев, О.Н. Ларин. Перспективы создания региональной бюджетной авиакомпании

Таблица 2

Пассажиропоток 20 крупнейших российских авиакомпаний за 2019 г. и за кризисный 2020 г., пассажиров

\begin{tabular}{|l|c|c|c|}
\hline \multicolumn{1}{|c|}{ Авиакомпания } & $\begin{array}{c}\text { Пассажиропоток } \\
\text { за 2019 г., пасс. }\end{array}$ & $\begin{array}{c}\text { Пассажиропоток } \\
\text { за 2020 г., пасс. }\end{array}$ & $\%, 2020 / 2019$ \\
\hline «Аэрофлот» & 37220668 & 14563135 & $-60,9$ \\
\hline «Сбирь» (S7) & 14046452 & 12349229 & $-12,1$ \\
\hline «обеда» & 10287223 & 9086736 & $-11,4$ \\
\hline «Россия» & 11553056 & 5710793 & $-50,6$ \\
\hline «Уральские Авиалинии» & 9616908 & 5632152 & $-38,7$ \\
\hline «ЮТэйр» & 7760642 & 4758390 & $-48,7$ \\
\hline «Северный Ветер» & 5536177 & 2939149 & $-46,9$ \\
\hline «Азур Эйр» & 5788726 & 1930037 & $-66,7$ \\
\hline «Смарт Авиа» & 2033375 & 1637603 & $-19,5$ \\
\hline «Ред Вингс» & 3070691 & 1536902 & $-49,9$ \\
\hline «Азимут» & $\mathbf{1 2 4 7 4 4 6}$ & $\mathbf{1 2 2 1 6 3 8}$ & $\mathbf{- 2 , 1}$ \\
\hline «Роял Флайт» & 2258915 & 917313 & $-59,4$ \\
\hline «Норд Стар» & 1283476 & 877141 & $-31,7$ \\
\hline «Аврора» & 1657741 & 795873 & -52 \\
\hline «Икар» & 2161817 & 760085 & $-64,8$ \\
\hline «Ямал» & 1746176 & 698278 & -60 \\
\hline «Ир Аэро» & 908505 & 591830 & $-44,9$ \\
\hline «Якутия» & 713150 & 499511 & -30 \\
\hline «Руслайн» & 635351 & 374822 & -41 \\
\hline «Алроса» & 491845 & 368968 & -25 \\
\hline
\end{tabular}

Примечание. Составлено авторами по: [Федеральное агентство воздушного транспорта. РОСАВИАЦИЯ].

ющих эксплуатацию воздушных судов иностранного производства. На фоне падения объемов оборотов, обусловленного резким снижением спроса и введением временных запретительных и ограничительных мер на выполнение международного регулярного пассажирского авиасообщения, возросла величина лизинговых платежей. Так, российская бюджетная авиакомпания «Победа» была вынуждена на 2 месяца приостановить полеты с 1 апреля 2020 г. по 31 мая 2020 г. [«Победа» приостанавливает выполнение ...], с целью минимизации затрат на лизинг по согласованию с лизингодателем. Парк воздушных судов авиакомпании «Победа» составляют лайнеры Boeing-737-800.

Важно отметить, что развитие регионального авиасообщения запускает процесс развития отечественной отрасли гражданского самолетостроения. При всех негативных моментах прошедшего года, а именно: на фоне макроэкономической нестабильности, курсовой неустойчивости национальной валюты, падения пассажиропотока, авиакомпания «Азимут» завершила 2020 г. с минимальным показателем падения пассажиропотока, расширив при этом парк воздушных судов на 2 единицы. Авиаперевозчик «Азимут», как российская региональная авиакомпания - эксплуатант отечественного лайнера «SSJ-100», является примером, доказывающим эффективность следующих составляющих элементов успеха: эксплантации лайнеров собственного производства, расширения региональной маршрутной сети, развития программы субсидирования региональных авиаперевозок как стимула развития спроса на внутреннем рынке. В конце прошлого года авиакомпания «Азимут» анонсировала открытие с января 2021 г. новых направлений, в том числе субсидируемых. В текущем году «Азимут» планирует открыть до 20 новых направлений на базе аэропорта г. Ставрополь. На данный момент (февраль 2021 г.) проходят переговоры между руководством авиакомпании и аэропорта, определяются направления расширения маршрутной сети [Авиакомпания Азимут развивает ...]. Аэропорт г. Ставрополь (СКФО) имеет высокие темпы роста и развития, в том числе за счет увеличение внутреннего туристического потока.

Важно отметить, что после ввода в эксплуатацию автомобильной и железнодорож- 
ной частей крымского моста количество туристов, пребывающих на полуостров авиационным транспортом, сократилось, оставшись на уровне $33-37 \%$. Необходимо учитывать специфику региональной логистической системы. Жители регионов ЮФО и СКФО предпочитают пользоваться услугами железнодорожного или частного автомобильного транспорта. Однако для жителей других регионов: ЦФО, СЗФО, ПФО, УФО и СФО авиационный транспорт является важной составляющей при посещении Республики Крым.

\section{Теоретические основания}

\section{региональной логистической системы}

Проблемам развития транспортной инфраструктуры, как важного элемента развития логистической системы Республики Крым, посвящен ряд трудов российских ученых. В статье А.С. Трусевской и В.С. Терехиной «Тенденции развития туризма в Крыму» [Трусевская и др., 2018] авторы исследования заключают, что тенденция увеличения пассажиропотока Республики Крым является результатом модернизации транспортной инфраструктуры. В частности, завершение модернизации Международного аэропорта «Симферополь», запланированной на 2023 г., станет важным фактором в развитии регионального авиасообщения ЮФО, при этом аэропорт сможет значительно расширить пропускную способность, увеличив количество направлений регулярного пассажирского авиасообщения с городами Российской Федерации.

В статье С.П. Кирильчук, Е.В. Наливайченко «Развитие туристско-рекреационного комплекса Крыма» [Кирильчук и др., 2017] авторы утверждают, что туристический потенциал Республики Крым значительно выше действующих показателей туристического потока. Увеличение туристического потока в условиях модернизации транспортной системы полуострова будет происходить за счет развития новых, перспективных направлений туризма, в том числе за счет развития детского туризма.

В статье К.В. Лобас «Развитие детского туризма в Крыму» [Лобас, 2019] автор подчеркивает, что Республика Крым располагает значительным количеством объектов ис- торического и культурного значения, что является важным фактором в развитии направления детского туризма. В дополнение к заключению автора необходимо сказать, что с территории Крыма началось крещение Руси Святым Равноапостольным Князем Владимиром, а также на территории полуострова действует более 60 археологических объектов, представляющих особую историческую и культурную ценность. Знакомство школьников и студентов с историей на примере посещения объектов культурного и исторического наследия является важным элементом педагогической деятельности, направленной на развитие исторических и духовных знаний. При развитии направления детского туризма на территории Республики рекомендуемыми для посещения должны стать экскурсии: Херсонеса Таврического, Пантикапея, Бахчисарая, Кульчука, Артезиана, Судакской крепости и Старого Крыма. Знакомство с археологией Древнего Крыма окажет самое благотворное влияние на развитие и популяризацию исторических знаний, станет важной составляющей в укреплении патриотизма подрастающего поколения. Важно отметить, что археологические раскопки, осуществляемые на территории Республики Крым, происходят при участии организованных групп студентов гуманитарных специальностей из разных регионов нашей страны. Это стало возможным благодаря реализации федеральных и региональных программ по развитию образования и науки.

Следует также отметить, что осуществление логистики школьников и студентов к местам отдыха является организационно сложным процессом. Для жителей населенных пунктов, расположенных на расстоянии более 500 км, предпочтительным является авиационный транспорт. Для поездки в Республику Крым организованной группы школьников или студентов, проживающих на территории областей, не имеющих прямого авиасообщения с Крымом, логистика осложняется рядом факторов: необходимостью промежуточной стыковки в Москве (при использовании авиасообщения), что влияет на удорожание стоимости авиаперелета; использованием автомобильного и железнодорожного транспорта к пункту вылета / прилета, что увеличивает затраты, время и влечет за собой риски. 
В.В. Рублев, О.Н. Ларин. Перспективы создания региональной бюджетной авиакомпании

Аварийность на железнодорожном и автомобильном транспорте является базовым риском при организации детского отдыха. Так, по итогам 2020 г. на дорогах РФ погибло более 430 детей, пострадало более 15,5 тыс. чел. [Более 430 детей ...]. Железная дорогая является также зоной повышенной опасности. Несмотря на общую динамику снижения происшествий, по итогам 2020 г. только на территории Московской области погибло свыше 260 человек [Более 260 человек погибли ...].

Приоритетным направлением в развитии туризма на территории Республики Крым может стать расширение действующей маршрутной сети Международного аэропорта «Симферополь» с регионами ЦФО, ПФО, СЗФО, УФО и СФО.

\section{Результаты исследования}

Проблема развития региональных аэропортов на островных и полуостровных территориях остается важным вопросом в организации национальной системы логистики государств. Так, на территории о. Корсика (Франция) действует четыре региональных аэропорта (Кальви, Аяччо, Бастия, Фигари), а на территории о. Сардиния (Италия) функционирует три региональных аэропорта (Кальяри, Ольбия, Альгеро).

Аэропорты острова Корсика являются хабами для французской региональной авиакомпании «Air Corsica» (классический авиаперевозчик). Флот авиакомпании состоит из
5 ед. Airbus A-320-200 и 4 ед. ATR-72-500. Вместимость Airbus A-320-200 составляет 180 пассажиров, а вместимость ATR-72-500 70 человек. Маршрутная сеть авиакомпании связывает аэропорты о. Корсика с Парижем (Орли) и крупными городами материковой Франции: Ницца, Марсель, Бордо, Тулуза, Страсбург, Лиль, Лион [Авиакомпания «Air Corsica»]. На внутреннем рынке «Air Corsica» конкурирует с национальным авиаперевозчиком «Air France». Международные рейсы с территории региональных аэропортов осуществляют бюджетные авиакомпании: «Volotea» (Испания), «еasyJet» (Великобритания) и «Ryanair» (Ирландия).

Рассмотрим структуры маршрутной сети региональных аэропортов о. Корсика с целью определения доли направлений классических и бюджетных авиакомпаний по состоянию на 2021 год (рис. 2).

Мы видим, что классические авиакомпании («Air France» и «Air Corsica») занимают ключевую позицию в структуре маршрутной сети трех аэропортов острова. Исключение - аэропорт г. Бастия, где доля направлений бюджетных авиакомпаний составляет $54,55 \%$. Следует отметить, что отличительной особенностью туристического потока о. Корсика является преобладание внутреннего туризма над иностранными гражданами. То есть основу туристического потока составляют граждане Франции (более 65 \%). Иностранные туристы отдают предпочтение отдыху на территории островов Сардиния и Сицилия в Италии, ввиду более развитой маршрут-

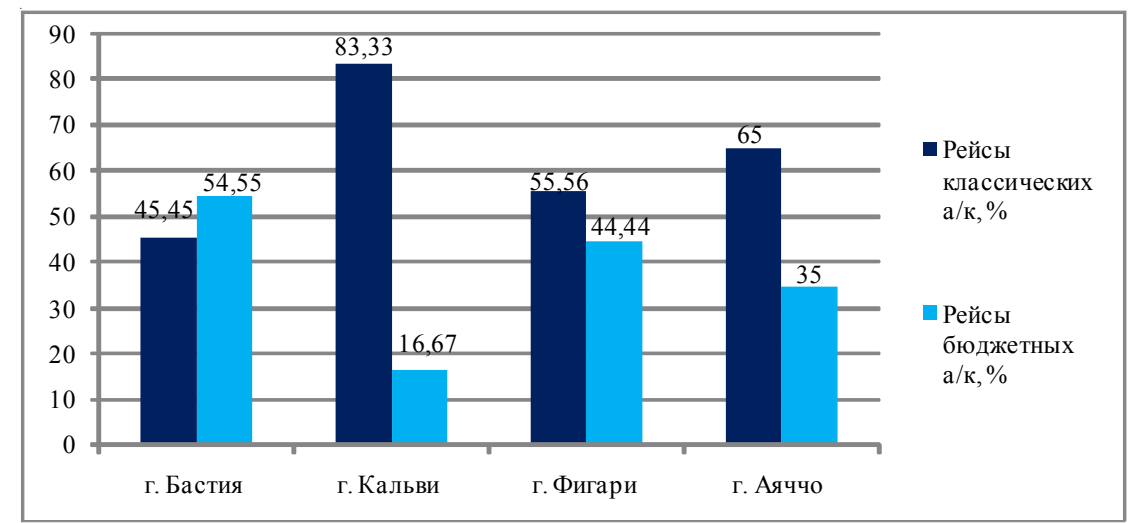

Рис. 2. Доля рейсов классических и бюджетных авиакомпаний в структуре маршрутной сети аэропортов о. Корсика (Франция), \%

Примечание. Составлено авторами по: [Resultats d'activite des aeroports francais -2019 .., 2020]. 
ной сети региональных аэропортов и более низкой стоимости туристических услуг. Так, совокупный показатель пассажиропотока всех четырех аэропортов о. Корсика по итогам работы за 2019 (докризисный) год составил 4 263,3 тыс. пассажиров, что ниже показателя пассажиропотока всего одного регионального аэропорта о. Сардиния, Кальяри - Элмас, пассажиропоток которого за 2019 г. был 4 747,8 тыс. пассажиров.

Приведем данные анализа структуры маршрутной сети аэропорта Кальяри - Элмас. По состоянию на 2021 г., по внутренним направлениям аэропорт связан регулярным пассажирским авиасообщением с 19 итальянскими городами: Анкона, Бари, Бергамо, Болонья, Катания, Милан, Кунео, Генуя, Неаполь, Палермо, Парма, Пескара, Пиза, Рим, Турин, Тревизо, Триесте, Венеция, Верона. Международную маршрутную сеть аэропорта Кальяри - Элмас составляют 44 направления: Аликате, Гамбург, Амстердам, Афины, Барселона, Бразилиа, Берлин, Бильбао, Бордо, Бреславия, Брюссель, Будапешт, Колонья, Краковица, Дёвиль, Дублин, Дюссельдорф, Франкфурт-на-Майне, Женева, Ганновер, Карлсруэ-Баден, Ганновер, Лиль, Лион, Лондон, Люксембург, Мадрид, Мальта, Манчестер, Марсель, Москва, Нант, Ницца, Прага, Париж, Порту, Севилья, Стоккрада, Страсбург, Тулуза, Валенсия, Варсавия, Вена, Цюрих [Cagliari Airport. Destinazioni]. Доля направлений бюджетных авиакомпаний в структуре маршрутной сети аэропорта Кальяри - Элмас составляет более $80 \%$, базовой классической авиакомпанией является итальянская «Alitalia», связывающая аэропорт регулярными сообщениями с городами Италии. Ведущие бюджетные авиаперевозчики в структуре маршрутной сети данного аэропорта представлены следующими авиакомпаниями: «Volotea» и «Vueling» (Испания), «easyJet» (Великобритания) и «Ryanair» (Ирландия).

На основании приведенных данных мы можем констатировать, что развитость маршрутной сети аэропорта наряду с расширением направлений бюджетных авиакомпаний (ключевая позиция в структуре маршрутной сети аэропорта) являются основополагающими факторами высокого уровня пассажи- ропотока. Напомним, что на территории о. Сардиния действует еще два региональных аэропорта: аэропорт Ольбия с пассажиропотоком 2 978,8 тыс. пассажиров за 2019 г. и аэропорт Альгеро с пассажиропотоком 1 390,4 тыс. пассажиров за тот же отчетный период. Таким образом, совокупный пассажиропоток трех аэропортов острова Сардиния превышает в 2 раза совокупный пассажиропоток четырех аэропортов острова Корсика.

Вернемся к теме исследования и рассмотрим данные анализа маршрутной сети Международного аэропорта «Симферополь» по состоянию на 2021 г. (зимнее расписание) (см. табл. 3).

Нетрудно заметить, что наибольший авиационный трафик по направлению Симферополь - Москва. На данном направлении пассажирские авиаперевозки осуществляет 9 авиакомпаний из 4 аэропортов Московского авиационного узла (МАУ). Таким образом, мы можем констатировать неравномерное распределение пассажиропотока по направлениям. Туристы из регионов РФ используют аэропорты МАУ в качестве транзитных хабов, при осуществлении перелетов на территорию Республики Крым.

В перечень субсидируемых направлений между регионами РФ и Республикой Крым по состоянию на 2021 г., размещенном на сайте Федерального агентства воздушного транспорта, приведены следующие данные (см. табл. 4).

Следует заметить, что значительная часть направлений - сезонные рейсы, осуществляемые с апреля по октябрь.

Как было отмечено выше, с момента вхождения Республики Крым в состав Российской Федерации Международный аэропорт «Симферополь» значительно расширил маршрутную сеть регулярного пассажирского авиасообщения. Это является обусловливающим фактором роста пассажиропотока аэропорта и увеличения общего туристического потока полуострова. Строительство и ввод в эксплуатацию автомобильной и железнодорожной частей крымского моста увеличило общий туристический поток, сократив количество туристов, пребывающих в Крым авиационным транспортом. 
B.B. Рублев, О.Н. Ларин. Перспективы создания региональной бюджетной авиакомпании

Направления маршрутной сети Международного аэропорта «Симферополь»

Таблица 3

по состоянию на февраль 2021 г.

\begin{tabular}{|c|c|}
\hline Направление & Авиакомпания \\
\hline г. Москва (Шереметьево) & $\begin{array}{l}\text { «Аэрофлот» } \\
\text { «Россия» } \\
\text { «Нордвинд» }\end{array}$ \\
\hline г. Москва (Домодедово) & $\begin{array}{l}\text { «S7» } \\
\text { «Уральские Авиалинии» } \\
\text { «Алроса» } \\
\text { «Ред Вингс» } \\
\text { «Ир Аэро» }\end{array}$ \\
\hline г. Москва (Внуково) & «Якутия» \\
\hline г. Москва (Жуковский) & «Уральские Авиалинии» \\
\hline г. Санкт-Петербург (Пулково) & $\begin{array}{l}\text { «Россия» } \\
\text { «Ред Вингс» } \\
\text { Нордвинд» }\end{array}$ \\
\hline г. Минеральные Воды & «Азимут» \\
\hline г. Ростов-на-Дону & «Азимут» \\
\hline г. Сочи & «Уральские Авиалинии» \\
\hline г. Екатеринбург & $\begin{array}{l}\text { «Уральские Авиалинии» } \\
\text { «Россия» }\end{array}$ \\
\hline г. Казань & $\begin{array}{l}\text { «Уральские Авиалинии» } \\
\text { «Нордвинд» } \\
\text { «Пегас Флай» }\end{array}$ \\
\hline г. Краснодар & «Азимут» \\
\hline г. Новосибирск & $\langle\mathrm{S} 7 »$ \\
\hline г. Новый Уренгой & «Ир Аэро» \\
\hline г. Самара & «Уральские Авиалинии» \\
\hline г. Уфа & «Ир Аэро» \\
\hline г. Череповец & «Северсталь» \\
\hline г. Якутск & «Якутия» \\
\hline
\end{tabular}

Примечание. Составлено авторами по: [Международный аэропорт «Симферополь»].

Таблица 4

Субсидируемые направления в Республику Крым по состоянию на 2021 г.

\begin{tabular}{|c|c|c|}
\hline Авиакомпания & Направление & $\begin{array}{l}\text { Стоимость авиабилета } \\
\text { с учетом субсидии, руб. }\end{array}$ \\
\hline «Аэрофлот» & г. Красноярск & 7000 \\
\hline «Аэрофлот» & г. Сочи & 2500 \\
\hline «Ред Вингс» & г. Нижний Новгород & 3375 \\
\hline «Ред Вингс» & г. Челябинск & 3750 \\
\hline «Ред Вингс» & г. Самара & 3375 \\
\hline «Ред Вингс» & г. Казань & 2750 \\
\hline «Ред Вингс» & г. Тюмень & 4250 \\
\hline «Уральские Авиалинии» & г. Екатеринбург & 3750 \\
\hline «Уральские Авиалинии» & г. Самара & 3375 \\
\hline «Уральские Авиалинии» & г. Челябинск & 3750 \\
\hline «Уральские Авиалинии» & г. Барнаул & 6250 \\
\hline «Уральские Авиалинии» & г. Казань & 2750 \\
\hline «Уральские Авиалинии» & г. Кемерово & 6250 \\
\hline «Уральские Авиалинии» & г. Омск & 5000 \\
\hline «Уральские Авиалинии» & г. Пермь & 3500 \\
\hline «Уральские Авиалинии» & г. Тюмень & 4250 \\
\hline «Уральские Авиалинии» & г. Чита & 8875 \\
\hline «Уральские Авиалинии» & г. Томск & 6250 \\
\hline «Уральские Авиалинии» & г. Иркутск & 8500 \\
\hline
\end{tabular}

Примечание. Составлено авторами по: [Федеральное агентство воздушного транспорта (Росавиация)]. 
Окончание таблищь 4

\begin{tabular}{|c|c|c|}
\hline Авиакомпания & Направление & $\begin{array}{l}\text { Стоимость авиабилета } \\
\text { с учетом субсидии, руб. }\end{array}$ \\
\hline «Уральские Авиалинии» & г. Нижневартовск & 5500 \\
\hline «Уральские Авиалинии» & г. Новосибирск & 6000 \\
\hline «Уральские Авиалинии» & г. Нижний Новгород & 3375 \\
\hline «Уральские Авиалинии» & г. Сочи & 2500 \\
\hline «Уральские Авиалинии» & г. Сургут & 5250 \\
\hline «Нордавиа» & г. Архангельск & 3750 \\
\hline «Нордавиа» & г. Белгород & 2500 \\
\hline «Нордавиа» & г. Волгоград & 2500 \\
\hline «Нордавиа» & г. Иваново & 3375 \\
\hline «Нордавиа» & г. Казань & 2750 \\
\hline «Нордавиа» & г. Мурманск & 3750 \\
\hline «Нордавиа» & г. Нижнекамск & 3750 \\
\hline «Нордавиа» & г. Нижний Новгород & 3375 \\
\hline «Нордавиа» & г. Оренбург & 3375 \\
\hline «Нордавиа» & г. Сыктывкар & 3750 \\
\hline «Нордавиа» & г. Уфа & 3125 \\
\hline «Нордавиа» & г. Чебоксары & 3375 \\
\hline «Азимут» & г. Ростов-на-Дону & 2500 \\
\hline «Азимут» & г. Минеральные Воды & 2500 \\
\hline «Ир Аэро» & г. Воронеж & 2500 \\
\hline «Ир Аэро» & г. Курск & 2500 \\
\hline «Сибирь» & г. Иркутск & 8500 \\
\hline «Сибирь» & г. Новосибирск & 6000 \\
\hline «Алроса» & г. Новосибирск & 6000 \\
\hline «Алроса» & г. Томск & 6250 \\
\hline «Алроса» & г. Кемерово & 6250 \\
\hline «Алроса» & г. Тюмень & 4250 \\
\hline «Алроса» & г. Иркутск & 8500 \\
\hline «Алроса» & г. Уфа & 3125 \\
\hline «Северный Ветер» & г. Тюмень & 4250 \\
\hline «Северный Ветер» & г. Красноярск & 7000 \\
\hline «Северный Ветер» & г. Томск & 6250 \\
\hline «Северный Ветер» & г. Барнаул & 6250 \\
\hline «Северный Ветер» & г. Магнитогорск & 5000 \\
\hline «Северный Ветер» & г. Волгоград & 2500 \\
\hline «Северный Ветер» & г. Самара & 3375 \\
\hline «Северный Ветер» & г. Новокузнецк & 6000 \\
\hline «Северный Ветер» & г. Саратов & 2500 \\
\hline «Северный Ветер» & г. Белгород & 2500 \\
\hline «Северный Ветер» & г. Екатеринбург & 3750 \\
\hline «Северный Ветер» & г. Челябинск & 3750 \\
\hline «Северный Ветер» & г. Оренбург & 3375 \\
\hline «Северный Ветер» & г. Нижнекамск & 3375 \\
\hline «Северный Ветер» & г. Ханты-Мансийск & 6875 \\
\hline «Северный Ветер» & г. Пермь & 3500 \\
\hline «Северный Ветер» & г. Киров & 3550 \\
\hline «Северный Ветер» & г. Омск & 3550 \\
\hline «Северный Ветер» & г. Воронеж & 5000 \\
\hline «Северный Ветер» & г. Нижний Новгород & 2500 \\
\hline «Северный Ветер» & г. Чебоксары & 3375 \\
\hline «Северный Ветер» & г. Ульяновск & 3375 \\
\hline
\end{tabular}


В зимний период времени, согласно зимнему сезонному расписанию, наблюдается неравномерная динамика авиационного трафика - сокращается количество направлений из регионов, преобладающую роль в структуре пассажиропотока занимает направление Симферополь - Москва. В летний период времени, за счет программы субсидирования авиаперевозок, маршрутная сеть аэропорта значительно расширяется, Симферополь осуществляет регулярное пассажирское авиасообщение со всеми крупными городами ЮФО, ЦФО, СЗФО, ПФО, УФО и СФО. Программа субсидирования позволяет приобретать льготным категориям граждан авиабилеты по фиксированной цене, которая значительно ниже стоимости билета на железнодорожный транспорт по аналогичному направлению. Данная мера стимулирует спрос, увеличивает показатель средней загруженности салонов воздушных судов, минимизирует возможные финансовые риски авиакомпаний.

\section{Выводы}

Возможным сценарием развития Международного аэропорта «Симферополь» может стать создание региональной авиакомпании на территории Республики Крым. На российском рынке пассажирских авиаперевозок действует авиакомпания «Победа», которая входит в структуру Группы «Аэрофлот». Парк авиакомпании составляют 30 ед. Boeing 737-800, pacсчитанные на перевозку 189 пассажиров. Данная авиакомпания не осуществляет авиасообщения с полуостровом Крым. Таким образом, доля направлений бюджетных авиакомпаний в структуре аэропорта составляет $0 \%$. Далее, как было отмечено выше, российская региональная авиакомпания «Азимут» выполняет регулярные рейсы только по двум направлениям, и это - единственная российская региональная авиакомпания, имевшая минимальный уровень падения пассажиропотока за кризисный 2020 г. и увеличившая парк воздушных судов в условиях макроэкономической нестабильности. Опыт развития российской региональной авиакомпании «Азимут» может послужить основой при разработке концепции развития региональной бюджетной авиакомпании Республики Крым. Важно отметить, что
«Азимут» была образована в 2017 г. и за 4 года деятельности на рынке укрепила свои позиции, заняв 11-е место в списке крупнейших национальных авиакомпаний.

В 2017 г. на территории Республики Азербайджан была образована национальная бюджетная авиакомпания «Buta Airways», которая по итогам за 2019 г. (через 2 года на рынке авиаперевозок) заняла 15 \% в структуре пассажиропотока аэропорта г. Баку [Аэропорты Азербайджана в 2019 году ...]. Данная авиакомпания является дочерней структурой национального авиаперевозчика «AZAL». Парк авиакомпании состоит из 8 ед. Embraer ERJ-190 вместимостью до 110 пассажиров (по состоянию на февраль 2021 г.) [Buta Airways Fleet Details and History].

В 2018 г. на территории Республики Казахстан, по инициативе президента Н.А. Назарбаева, на базе национального авиаперевозчика «Air Astana» была образована первая казахстанская бюджетная авиакомпания «Fly Arystan». В парке авиакомпании 7 ед. Airbus A-320-200 вместимостью до 180 пассажиров, ранее эксплуатируемых авиакомпанией «Air Astana» [Planespotters. Fly Arystan]. За два года работы на рынке, авиакомпания «Fly Arystan» выстроила разветвленную маршрутную сеть, связывающую г. Нур-Султан и г. Алматы со всеми крупными городами Республики Казахстан, а в декабре 2019 г. открыла регулярное авиасообщение между г. Нур-Султан и г. Москва (Жуковский). В 2020 г. авиакомпания «Fly Arystan» анонсировала приобретение 30 ед. Boeing 737 MAX, с целью укрепления на рынке пассажирских авиаперевозок. В случае реализации программы по приобретению лайнеров, Республика Казахстан станет ведущим региональным лидером в сегменте бюджетных авиаперевозок [Рублев, 2020в].

При проведении комплексного исследования по выбранной теме необходимо рассмотреть последние достижения отечественного самолетостроения. По состоянию на 2021 г. произведено более 200 ед. российского лайнера «SSJ-100». Крупнейшими эксплуатантами данного воздушного судна являются: «Аэрофлот» (54 ед.), «Ямал» (15 ед.), «Россия» (13 ед.), «Азимут» (13 ед.), «Газпромавиа» (10 ед.), «Ир Аэро» (9 ед.) [Список про- 
изведенных самолетов ...]. За время эксплуатации лайнер доказал свою эксплуатационную эффективность на рынке региональных авиаперевозок. Пример авиакомпании "Азимут» является подтверждением эффективной результативности эксплуатации лайнеров в условиях макроэкономической нестабильности, падения спроса и девальвации национальной валюты. В январе 2021 г. руководство корпорации «Иркут» анонсировало планы по выкупу лайнеров «SSJ-100» в количестве 6 ед., ранее проданных ирландской региональной авиакомпании «City Jet», в связи с возросшим спросом на внутреннем рынке [Россия заберет за деньги ...]. На фоне падения рынка пассажирских авиаперевозок в Европе (более $70 \%)$ и отказа части европейских авиакомпаний от планов по приобретению новых воздушных судов, на внутреннем рынке России возрос спрос на среднемагистральные воздушные суда.

В структуре европейского рынка пассажирских авиаперевозок доля пассажиропотока бюджетных авиакомпаний в 2009 г. не превышала $15 \%$, по итогам деятельности за 2019 г. совокупный объем пассажиропотока европейских бюджетных авиакомпаний достиг показателя 50 \% [Рублев, 2020б].

В структуре российского рынка, по итогам за 2019 г., доля пассажиропотока российской бюджетной авиакомпании «Победа» и иностранных бюджетных авиакомпаний, выполняющих регулярные рейсы в Россию, не превышала $15 \%$. Сегмент бюджетных авиаперевозок в России останется не развитым, что предоставляет особые возможности при создании авиакомпаний в бюджетном сегменте авиаперевозок, например, на базе аэропорта «Симферополь».

Согласно плану Министерства транспорта РФ, представленному министром транспорта В.Г. Савельевым в середине 2020 г. премьерминистру М.В. Мишустину [Савельев представил Мишустину ...], ключевым фактором посткризисного развития российского рынка пассажирских авиаперевозок станет увеличение доли бюджетных авиаперевозок в структуре рынка. Посткризисный рост рынка будет обеспечиваться за счет развития конкуренции в сегменте бюджетных авиаперевозок и появления новых бюджетных авиакомпаний.
Технические возможности лайнера «SSJ-100» позволяют совершать беспосадочные полеты на расстояние от 3000 (модификация 100-95 В) до 4500 км (модификация 100-95 LR). Таким образом, модификации 100-95 лайнера позволяют осуществлять полеты по территориям ЮФО, СКФО, ЦФО, СЗФО, ПФО и УФО. Кроме этого, лайнер в модификации 100-95 LR в дополнение к представленным регионам покрывает территорию СФО. В настоящее время готовится к серийному выпуску и проходит стадию летно-технических испытаний новейший российский пассажирский узкофюзеляжный среднемагистральный лайнер «МС-21». Заявленные технические характеристики лайнера следующие: вместимость от 132 до 211 пассажиров, максимальная дальность полета до 6000 км [Самолет MC-21]. По состоянию на 2021 г. в портфеле заказов более 100 лайнеров. Предполагаемая дата передачи первого лайнера заказчику 2022 год.

Создание региональной бюджетной авиакомпании на территории Республики Крым необходимо осуществлять при участии федеральных и республиканских органов исполнительной власти. Разработка региональных программ субъектов РФ по развитию детского сезонного туризма на территории Республики Крым послужит ключевым фактором роста пассажиропотока и востребованности авиационных направлений. Расширение действующей программы субсидирования региональных авиаперевозок и включение в состав льготных категорий, например: работников сферы науки, образования, культуры и искусства, а также семей военнослужащих и работников силовых ведомств может послужить еще одним фактором, оказывающим положительное влияние на развитие внутреннего туризма.

На фоне сокращения среднестатистического падения пассажиропотока региональных аэропортов РФ более чем на 40 \%, пассажиропоток Международного аэропорта «Симферополь» сократился на 10 \% [Пассажиропоток аэропорта Симферополя ...], а пассажиропоток аэропорта «Геленджик» в кризисный 2020 г. вырос на 42 \% [Пассажиропоток аэропорта Геленджик ...]. Пассажиропоток региональных аэропортов ЦФО - «Туношна» 
(г. Ярославль) в прошлом году вырос на рекордные 70,52 \%, а пассажиропоток аэропорта г. Курска увеличился на 47,5 \% [Аэропорт Курска в 2020 г. ...]. В обоих случаях фактором роста пассажиропотока стало открытие направлений, связавших Ярославль и Курск с городами ЮФО. Это является еще одним фактором, доказывающим востребованность регионального авиасообщения, и подтверждает необходимость создания региональной авиакомпании на территории Республики Крым. Создание региональной авиакомпании в бюджетном сегменте может стать более эффективным в условиях посткризисного восстановления рынка пассажирских авиаперевозок.

Обоснованием целесообразности создания региональной авиакомпании на территории Республики Крым может послужить экономический эффект для национальной и региональной экономики. Приведем данные экономического эффекта для национальной и региональной экономики (табл. 5) в результате создания региональной авиакомпании с базовым аэропортом (хабом) на территории Республики Крым.

Анализируя французский опыт создания региональной авиакомпании «Air Corsica» на территории острова Корсика, мы можем заключить, что данная авиакомпания проигрыва- ет конкурентную борьбу бюджетным авиакомпаниям, осуществляющим региональные рейсы из аэропортов Бастии, Кальви, Аяччо и Фигари. Стоимость билетов «Air Corsica» выше стоимости авиабилетов бюджетных авиакомпаний «easyJet» и «Volotea», что негативным образом сказывается на загруженности самолетов «Air Corsica» и, следовательно, на финансовых результатах авиакомпании. При этом французская региональная авиакомпания «Air Corsica» выполняет важную задачу в организации национальной логистической системы. В 2020 г., в период введения временных ограничительных мер на осуществление международного авиасообщения, только «Air Corsica» и «Air France» выполняли регулярные рейсы из корсиканских аэропортов. Переход авиакомпании «Air Corsica» в бюджетный сегмент будет способствовать увеличению пассажиропотока и, таким образом, расширению парка ВС авиакомпании и открытию новых направлений. «Air Corsica» сможет эффективно конкурировать с другими бюджетными авиакомпаниями, осуществляющими регулярные пассажирские рейсы на остров Корсика, и в итоге островные аэропорты увеличат пассажиропоток.

Анализируя итальянский опыт, мы можем заключить, что отсутствие региональной

Таблииа 5

\section{Экономический эффект для национальной и региональной экономики} при создании региональной авиакомпании на территории Республик Крым

\begin{tabular}{|c|c|}
\hline $\begin{array}{c}\text { Экономический эффект для национальной экономики } \\
\text { (Российская Федерация) }\end{array}$ & $\begin{array}{c}\text { Экономический эффект для региональной экономики } \\
\text { (Республика Крым) }\end{array}$ \\
\hline $\begin{array}{l}\text { Поддержка национальной системы гражданского само- } \\
\text { летостроения (потребность среднестатистической } \\
\text { региональной авиакомпании - } 10-15 \text { ед. BC «SSJ-100» } \\
\text { или «MC-21») }\end{array}$ & $\begin{array}{l}\text { Увеличение туристического потока из регионов РФ за } \\
\text { счет развития новых направлений туризма: санаторно- } \\
\text { курортное лечение граждан пенсионного возраста и } \\
\text { льготных категорий, а также развитие сегмента детско- } \\
\text { го туризма }\end{array}$ \\
\hline Развитие национальной системы внутреннего т & $\begin{array}{l}\text { Увеличение пассажиропотока «Международного аэро- } \\
\text { порта Симферополь» (до 1,5-2 млн пассажиров в год) }\end{array}$ \\
\hline $\begin{array}{l}\text { Укрепление межрегионального экономического взаи- } \\
\text { модействия (стратегически важная задача в условиях } \\
\text { санкционного давления со стороны ряда зарубежных } \\
\text { государств) }\end{array}$ & $\begin{array}{l}\text { Создание до } 1000 \text { новых рабочих мест на территории } \\
\text { Республики Крым (численность работников авиаком- } \\
\text { пании с парком ВС в количестве } 10-15 \text { ед.) }\end{array}$ \\
\hline $\begin{array}{l}\text { Развитие конкуренции на национальном рынке пасса- } \\
\text { жирских авиаперевозок }\end{array}$ & $\begin{array}{l}\text { Развитие структуры региональной логистической сис- } \\
\text { темы ЮФО (по развитости логистической системы } \\
\text { Республика Крым будет находиться на одном уровне с } \\
\text { ведущчими курортными регионами ЮФО и СКФО) }\end{array}$ \\
\hline $\begin{array}{l}\text { Развитие сегмента бюджетных авиаперевозок на на- } \\
\text { циональном рынке пассажирских авиаперевозок (при } \\
\text { условии создания региональной бюджетной авиаком- } \\
\text { пании) }\end{array}$ & $\begin{array}{l}\text { Минимизация рисков, связанных с введением эконо- } \\
\text { мической блокады Республики Крым со стороны Ук- } \\
\text { раины, и санкционного давления со стороны ряда зару- } \\
\text { бежных стран }\end{array}$ \\
\hline
\end{tabular}

Примечание. Разработано авторами. 
авиакомпании, базирующейся на территории островов Сардиния и Сицилия, оказывает негативное влияние на структуру национальной логистической системы Италии. Региональные аэропорты островов Сардиния и Сицилия зависимы в значительной степени от зарубежных авиаперевозчиков, которые контролируют до $90 \%$ направлений в структуре маршрутной сети аэропортов. Национальная авиакомпания «Alitalia» из региональных аэропортов Сардинии и Сицилии выполняет регулярные пассажирские рейсы, связывающие островные территории с Римом и крупными городами Италии (Милан, Генуя, Венеция, Неаполь). Создание региональной авиакомпании с аэропортами-хабами на территории региональных аэропортов островов Сардиния и Сицилия позволило бы Италии минимизировать зависимость от зарубежных авиакомпаний и увеличить туристический поток по внутренним направлениям. Учитывая специфику структуры маршрутной сети аэропортов Сардинии и Сицилии (доля направлений бюджетных авиакомпаний от 70 до $90 \%$ ), наиболее целесообразным стало бы создание итальянской региональной авиакомпании в бюджетном сегменте. Важно отметить, что Италия является одним из лидеров туристической индустрии Европы и не имеет собственной бюджетной авиакомпании.

При разработке проекта создания региональной авиакомпании на территории Республики Крым важно учитывать зарубежный опыт управления аэропортами на островных и полуостровных территориях и принимать во внимание специфику российского рынка пассажирских авиаперевозок. В научном исследовании А.И. Евтушенко, опубликованном в 2017 г. в издании «Символ науки», автор заключает, что независимость от факторов внешней среды (зарубежное влияние) должна стать основополагающим при разработке инфраструктуры Республики Крым [Евтушенко, 2017]. Таким образом, приоритетным направлением развития при создании региональной авиакомпании на территории Республики Крым может стать развитие маршрутной сети с регионами Российской Федерации.

Л.Д. Спасибенко подчеркивает, что проблемой в развитии туристического потенциала Республики Крым является низкий пока- затель загруженности объектов туристической инфраструктуры в зимний период времени [Спасибенко, 2015]. Таким образом, создание региональной авиакомпании на территории Республики Крым позволит увеличить туристический поток в зимний период времени, так как в настоящее время значительное количество направлений между Крымом и регионами Российской Федерации осуществляется сезонно (преимущественно в период с апреля по октябрь).

Учитывая тенденцию и динамику развития российского рынка пассажирских авиаперевозок, а также принимая во внимания показатели деятельности российских авиакомпаний в 2020 г. (см. табл. 2), мы можем заключить, что в условиях макроэкономической нестабильности, на фоне падения пассажиропотока классических авиакомпаний, возрастет спрос на субсидируемые и бюджетные авиаперевозки. Таким образом, создание региональной авиакомпании на территории Республики Крым, осуществляющей деятельность в сегменте бюджетных авиаперевозок, может стать одним из ключевых факторов эффективного развития. Российский рынок бюджетных авиаперевозок имеет высокие темпы роста и развития, при этом потенциал развития рынка значительно превосходит возможности единственной российской бюджетной авиакомпании «Победа».

В исследованиях А.В. Губенко, Ю.И. Растова, А.Р. Панкратова подчеркивается, что основным фактором развития российского рынка в условиях макроэкономической нестабильности будет развитие сегмента бюджетных авиаперевозок и образование новых региональных бюджетных авиакомпаний [Губенко и др., 2019]. Возможным сценарием развития сегмента бюджетных авиаперевозок исследователи видят переход действующих классических региональных российских авиакомпаний в бюджетный сегмент.

Для развития национальной системы гражданского самолетостроения необходимо стимулировать внутренний спрос на продукцию отечественных авиастроительных корпораций. Российская Федерация имеет все возможности для увеличения производства региональных лайнеров малой и средней протяженности вместимостью от 70 до 190 пассажиров [Реутова и др., 2018]. 
Таким образом, создание региональной авиакомпании на территории Республики Крым позволит российским авиастроительным корпорациям расширить свой производственный потенциал. Как было указано выше, опыт эксплуатации российских лайнеров «SSJ100» авиакомпанией «Азимут» доказывает их конкурентное преимущество перед зарубежными аналогами. Важно отметить, что значительная часть лайнеров в парке воздушных судов европейских авиакомпаний - лайнеры европейских авиастроительных корпораций «Airbus SE» и «ATR» [Ларин и др., 2020].

Политика протекционизма доказала свою эффективность и может быть реализована в Российской Федерации с целью развития национальной системы гражданского самолетостроения при создании региональной авиакомпании на территории Республики Крым. Создание региональной авиакомпании с базовым аэропортом на территории Крыма является важным элементом в развитии региональной авиатранспортной инфраструктуры, имеющей положительный эффект как для национальной, так и региональной экономики. Необходимость создания региональной авиакомпании обусловлена особым положением Республики Крым в обеспечении национальных интересов Российской Федерации. Попытки Украины и ряда зарубежных стран, выраженные в ведении «экономической блокады» и санкционного давления с целью дестабилизации социально-экономического положения Республики Крым, являются важным обусловливающим фактором в развитии экономического взаимодействия Крыма с регионами Российской Федерации с целью минимизации рисков от внешних негативных факторов.

Республика Крым имеет высокий потенциал развития туризма, и создание региональной авиакомпании может стать еще одним важным фактором в развитии национальной системы внутреннего туризма.

\section{СПИСОК ЛИТЕРАТУРЫ}

Авиакомпания Азимут развивает межрегиональные перевозки из Ставрополья. - Электрон. текстовые дан. - Режим доступа: https:// azimuth.aero/ru/news/aviakompaniya-azimutrazvivaet-mezhregionalnye-perevozki-iz- stavropolya (дата обращения: 11.02.2021). Загл. с экрана.

Авиакомпания «Азимут». Флот. - Электрон. текстовые дан. - Режим доступа: https://azimuth.aero/ ru/about/fleet (дата обращения: 11.02.2021). Загл. с экрана.

Авиакомпания «Air Corsica». - Электрон. текстовые дан. - Режим доступа: https://www. aircorsica.com/ (дата обращения: 11.02.2021). Загл. с экрана.

Аэропорт Курска в 2020 г. увеличил пассажиропоток на 47,5 \%. - Электрон. текстовые дан. Режим доступа: https:/news.myseldon.com/ru/ news/index/244892552 (дата обращения: 11.02.2021). - Загл. с экрана.

Аэропорты Азербайджана в 2019 году побили новый рекорд. - Электрон. текстовые дан. - Режим доступа: https://ru.baku.ws/hot_news/ 115120 (дата обращения: 11.02.2021). - Загл. с экрана.

«Аэропроект». - Электрон. текстовые дан. - Режим доступа: https://www.aeroproject.ru/info-centre/ news/2560/ (дата обращения: 11.02.2021). - Загл. с экрана.

Более 260 человек погибли на железных дорогах Подмосковья в 2020 году. - Электрон. текстовые дан. - Режим доступа: https:/iz.ru/ 1095392/2020-12-03/bolee-260-chelovek-pogiblina-zheleznykh-dorogakh-podmoskovia-v-2020godu (дата обращения: 11.02.2021). - Загл. с экрана.

Более 430 детей погибли на дорогах России с начала 2020 года. - Электрон. текстовые дан. - Режим доступа: https://tass.ru/proisshestviya/ 10160531/ (дата обращения: 11.02.2021). - Загл. с экрана.

Губенко, А. В. Современное состояние и перспективы развития рынка пассажирских авиаперевозок в России / А. В. Губенко, Ю. И. Растова, А. Р. Панкратова // Экономика и экологический менеджмент. - 2019. - № 2. - С. 82-90.

Евтушенко, А. И. Прогнозирование основных тенденций развития транспортной инфраструктуры полуострова Крым / А. И. Евтушенко // Символ науки. - 2017. - № 5. - С. 192-198.

Кирильчук, С. П. Развитие туристско-рекреационного комплекса Крыма / С. П. Кирильчук, Е. В. Наливайченко // Сервис в России и за рубежом. - 2017. - № 6 (76). - С. 109-125.

Крымская железная дорога за два года реконструирует 23 платформы. - Электрон. текстовые дан. Режим доступа: https://tass.ru/info/5200479 (дата обращения: 11.02.2021). - Загл. с экрана.

Крымский мост. Досье. - Электрон. текстовые дан. Режим доступа: https://tass.ru/info/5200479 (дата обращения: 11.02.2021). - Загл. с экрана. 
Ларин, О. Н. Перспективы развития европейской авиастроительной корпорации Airbus SE в условиях преодоления кризиса, вызванного пандемией COVID-19 / О.Н.Ларин, В. В. Рублев // KANT. - 2020. - № 4 (37), дек. - C. 160-168.

Лобас, К. В. Развитие детского туризма в Крыму / К. В. Лобас // Колпинские чтения по краеведению и туризму. - 2019. - № 4. - С. 86-91.

Международный аэропорт «Симферополь». Электрон. текстовые дан. - Режим доступа: https://new.sipaero.ru/passengers/schedule/ seasonal/ (дата обращения: 11.02.2021). - Загл. с экрана.

Пассажиропоток аэропорта Геленджик в 2020 году вырос на 42 \%. - Электрон. текстовые дан. Режим доступа: https:/www. finam.ru/analysis/ newsitem/passazhiropotok-aeroporta-gelendzhikv-2020-godu-vyros-na-42-20210112-102943/ (дата обращения: 11.02.2021). - Загл. с экрана.

Пассажиропоток аэропорта Симферополя в 2020 году снизился почти на $10 \%$. - Электpoн. текстовые дан. - Режим доступа: https:// tourism.interfax.ru/ru/news/articles/76160 (дата обращения: 11.02.2021). - Загл. с экрана.

«Победа» приостанавливает выполнение полетов до 31 мая 2020 года. - Электрон. текстовые дан. - Режим доступа: https://www.pobeda. aero/about/news/news-462/ (дата обращения: 11.02.2021). - Загл. с экрана.

Реутова, К. С. Иркутский Авиационный завод. Вехи истории, современное состояние и перспективы / К. С. Реутова, В. А. Ташкин // Актуальные проблемы авиации и космонавтики. 2018. - № 4 (14). - С. 877-891.

Россия заберет за деньги последние SSJ-100 в Европе. - Электрон. текстовые дан. - Режим доступа: https://lenta.ru/news/2021/01/25/ssj/ (дата обращения: 11.02.2021). - Загл. с экрана.

Рублев, В. В. Анализ эффективности мер государственной поддержки региональных пассажирских авиаперевозок в Российской Федерации / В. В. Рублев // Современная экономика: проблемы и решения. - 2020а. - № 7 (127), июль. С. 161-177.

Рублев, В. В. Европейский опыт развития бюджетных авиакомпаний на рынке региональных авиаперевозок: тенденции и перспективы развития / В. В. Рублев // Региональные проблемы преобразования экономики. - 2020б. № 6 (116), сент. - С. 24-33.

Рублев, В. В. Перспективы развития рынка бюджетных авиаперевозок в Республике Казахстан / В. В. Рублев // Вестник Астраханского государственного технического университета. Серия: Экономика. - 2020в. - № 2, июнь. C. $70-80$.
Савельев представил Мишустину обновленную стратегию развития «Аэрофлота». - Электрон. текстовые дан. - Режим доступа: https:// www.vedomosti.ru/business/articles/2020/07/ 14/834527-savelev-rasskazal-mishustinu (дата обращения: 11.02.2021). - Загл. с экрана.

Самолет МС-21: летно-технические характеристики. - Электрон. текстовые дан. - Режим доступа: https://ria.ru/20170528/1494560278.html (дата обращения: 11.02.2021). - Загл. с экрана.

Спасибенко, Л. Д. Развитие инфраструктуры Крыма как неотъемлемая часть развития экономики гостиничного и туристического бизнеса / Л. Д. Спасибенко // Стратегия устойчивого развития регионов России. - 2015. - № 25. С. $41-49$.

Список произведенных самолетов Суперджет-100. Электрон. текстовые дан. - Режим доступа: http://superjet.wikidot.com/wiki:produced (дата обращения: 11.02.2021). - Загл. с экрана.

Трусевская, А. С. Тенденции развития туризма в Крыму / А. С. Трусевская, В. С. Терехина // Творчество и современность. - 2018. № 1 (5). - С. 98-104.

Федеральное агентство воздушного транспорта (Росавиация). Субсидирование авиаперевозок. Электрон. текстовые дан. - Режим доступа: https://favt.gov.ru/dejatelnost-vozdushnyeperevozki-subsidirovanie/ (дата обращения: 11.02.2021). - Загл. с экрана.

Федеральное агентство воздушного транспорта. РОСАВИАЦИЯ. Перевозки пассажиров. Электрон. текстовые дан. - Режим доступа: https://favt.gov.ru/dejatelnost-vozdushnyeperevozki-perevozki-passazhirov/ (дата обращения: 11.02.2021). - Загл. с экрана.

Федеральное агентство воздушного транспорта (Росавиация). Субсидирование авиаперевозок в город Симферополь. - Электрон. текстовые дан. - Режим доступа: https://favt.gov.ru/ dejatelnost - vozdush nye-perevozki subsidirovanie-simferopol/ (дата обращения: 11.02.2021). - Загл. с экрана.

Федеральную трассу «Таврида» в Крыму полностью закончат в 2022 году. - Электрон. текстовые дан. - Режим доступа: https://tass.ru/info/ 5200479 (дата обращения: 11.02.2021). - Загл. с экрана.

Федеральный конституционный закон от 21.03.2014 № 6-ФКЗ (ред. от 30.12.2020) «О принятии в Российскую Федерацию Республики Крым и образовании в составе Российской Федерации новых субъектов - Республики Крым и города федерального значения Севастополя». - Доступ из справ.-правовой системы «КонсультантПлюс». 
Buta Airways Fleet Details and History. - Electronic text data. - Mode of access: https://www. planespotters.net/airline/Buta-Airways (date of access: 11.01.2021). - Title from screen.

Cagliari Airport. Destinazioni. - Electronic text data. Mode of access: http://www.sogaer.it/it (date of access: 11.02.2021). - Title from screen.

Planespotters. Fly Arystan. - Electronic text data. Mode of access: https://www.planespotters. net/airline/FlyArystan (date of access: 11.01.2021). - Title from screen.

Resultats d'activite des aeroports francais - 2019. Statistiques de traffic // UAF \& FRA (Union des Aeroports Francais \& Francophones Associes). - 2020. - $105 \mathrm{p}$.

\section{REFERENCES}

Aviakompaniya Azimut razvivayet mezhregionalnyye perevozki iz Stavropolia [Azimuth Airlines Develops Interregional Transportation from Stavropol]. URL: https://azimuth.aero/ru/news/ aviakompaniya-azimut-razvivaet-mezhregionalnyeperevozki-iz-stavropolya (accessed 11 February 2021).

Aviakompaniya «Azimut». Flot [Azimuth Airlines. Aircraft Fleet]. URL: https://azimuth.aero/ru/ about/fleet (accessed 11 February 2021).

Aviakompaniya «Air Corsica» [Airline "Air Corsica"]. URL: https://www.aircorsica.com/ (accessed 11 February 2021).

Aeroport Kurska v 2020 g. uvelichil passazhiropotok na 47,5\% [Kursk International Airport Increased Passenger Traffic by $47.5 \%$ in 2020]. URL: https://news.myseldon.com/ru/news/ index/244892552 (accessed 11 February 2021).

Aeroporty Azerbaydzhana v 2019 godu pobili novyy rekord [Azerbaijan's Airports Broke a New Record in 2019]. URL: https://ru.baku.ws/ hot_news/115120 (accessed 11 February 2021).

"Aeroproyekt»[“Aeroproject"]. URL: https:// www.aeroproject.ru/info-centre/news/2560/ (accessed 11 February 2021).

Boleye 260 chelovek pogibli na zheleznykh dorogakh Podmoskovia v 2020 godu [More Than 260 People Have Died on the Railways of the Moscow Region in 2020]. URL: https://iz.ru/ 1095392/2020-12-03/bolee-260-chelovek-pogiblina-zheleznykh-dorogakh-podmoskovia-v-2020godu (accessed 11 February 2021).

Boleye 430 detey pogibli na dorogakh Rossii s nachala 2020 goda [More Than 430 Children Have Died on the Roads of Russia Since the Beginning of 2020]. URL: https://tass.ru/proisshestviya/ 10160531/ (accessed 11 February 2021).
Gubenko A.V., Rastova Y.I., Pankratova A.R. Sovremennoye sostoyaniye i perspektivy razvitiya rynka passazhirskikh aviaperevozok v Rossii [The Current State and Prospects of Passenger Air Transportation Market Development in Russia]. Ekonomika $i$ ekologicheskiy menedzhment [Economics and Environmental Management], 2019, no. 2, pp. 82-90.

Yevtushenko A.I. Prognozirovaniye osnovnykh tendentsiy razvitiya transportnoy infrastruktury poluostrova Krym [Forecasting of the Main Trends in the Development of the Transport Infrastructure in the Crimean Peninsula]. Simvol nauki, 2017, no. 5, pp. 192-198.

Kirilchuk S.P., Nalyvaichenko E.V. Razvitiye turistskorekreatsionnogo kompleksa Kryma [Development of Tourism and Recreational Complex of Crimea]. Servis $v$ Rossii i za rubezhom [Services in Russia and Abroad], 2017, no. 6(76), pp. 109-125.

Krymskaya zheleznaya doroga za dva goda rekonstruiruyet 23 platformy [The Crimean Railway Will Reconstruct 23 Platforms in Two Years]. URL: https://tass.ru/info/5200479 (accessed 11 February 2021).

Krymskiy most. Dosye [The Crimean Bridge. The Dossier]. URL: https://tass.ru/info/5200479 (accessed 11 February 2021).

Larin O.N., Rublev V.V. Perspektivy razvitiya evropeyskoy aviastroitelnoy korporatsii Airbus SE v usloviyakh preodoleniya krizisa, vyzvannogo pandemiyey COVID-19 [Prospects for the Development of the European Aircraft Corporation Airbus SE in the Context of Overcoming the Crisis Caused by the COVID19 Pandemic]. KANT, 2020, no. 4 (37) (December), pp. 160-168.

Lobas K.V. Razvitie detskogo turizma v Krymu [Development of Children's Tourism in Crimea]. Kolpinskiye chteniya po krayevedeniyu $i$ turizmu [Kolpino Readings on Local Lore and Tourism], 2019, no. 4, pp. 86-91.

Mezhdunarodnyy aeroport «Simferopol» [Simferopol International Airport]. URL: https://new.sipaero. $\mathrm{ru} /$ passengers/schedule/seasonal/ (accessed 11 February 2021).

Passazhiropotok aeroporta Gelendzhik v 2020 godu vyros na $42 \%$ [Passenger Traffic at Gelendzhik Airport Increased by $42 \%$ in 2020]. URL: https://www.finam.ru/analysis/newsitem/ passazhiropotok-aeroporta-gelendzhik-v-2020godu-vyros-na-42-20210112-102943/ (accessed 11 February 2021).

Passazhiropotok aeroporta Simferopolya v 2020 godu snizilsya pochti na $10 \%$ [Passenger Traffic at Simferopol International Airport in 2020 
Decreased by Almost 10\%]. URL: https:// tourism.interfax.ru/ru/news/articles/76160 (accessed 11 February 2021).

«Pobeda» priostanavlivayet vypolneniye poletov do 31 maya 2020 goda [Pobeda Airlines is Suspending Flights Until May 31, 2020]. URL: https://www.pobeda.aero/about/news/news462/ (accessed 11 February 2021).

Reutova K.S., Tashkin V.A. Irkutskiy Aviatsionnyy zavod. Vekhi istorii, sovremennoye sostoyaniye i perspektivy [Irkutsk Aviation Factory. Milestones of History, Modern Condition and Perspectives]. Aktualnyye problemy aviatsii $i$ kosmonavtiki, 2018, no. 4(14), pp. 877-891.

Rossiya zaberet za dengi posledniye SSJ-100 v Evrope [Russia Will Buy the Last "SSJ-100" Jets in Europe]. URL: https://lenta.ru/news/2021/01/25/ ssj/ (accessed 11 February 2021).

Rublev V.V. Analiz effektivnosti mer gosudarstvennoy podderzhki regionalnykh passazhirskikh aviaperevozok v Rossiyskoy Federatsii [Analysis of the Effectiveness of State Support Measures for Regional Passenger Air Transport in the Russian Federation]. Sovremennaya ekonomika: problemy $i$ resheniya [Modern Economics: Problems and Solutions], 2020a, no. 7 (127) (July), pp. 161-177.

Rublev V.V. Evropeyskiy opyt razvitiya byudzhetnykh aviakompaniy na rynke regionalnykh aviaperevozok: tendentsii i perspektivy razvitiya [European Experience in Developing Low-Cost Airlines in the Regional Air Transportation Market: Development Trends and Prospects]. Regionalnyye problemy preobrazovaniya ekonomiki [Regional Problems of Transforming the Economy], 2020b, no. 6 (116) (September), pp. 24-33.

Rublev V.V. Perspektivy razvitiya rynka byudzhetnykh aviaperevozok v Respublike Kazakhstan [Development Prospects of Budget Passenger Air Transportation Market in Republic of Kazakhstan]. Vestnik Astrakhanskogo gosudarstvennogo tekhnicheskogo universiteta. Seriya: Ekonomika [Vestnik of Astrakhan State Technical University. Series: Economics], 2020v, no. 2 (June), pp. 70-80.

Savelyev predstavil Mishustinu obnovlennuyu strategiyu razvitiya «Aeroflota» [Saveliev Presented an Updated Aeroflot Development Strategy to Mishustin]. URL: https:// www.vedomosti.ru/business/articles/2020/07/ 14/834527-savelev-rasskazal-mishustinu (accessed 11 February 2021).

Samolet MS-21: letno-tekhnicheskiye kharakteristiki [The Irkut MC-21 Airliner: Aircraft Performance].
URL: https://ria.ru/20170528/1494560278.html (accessed 11 February 2021).

Spasibenko L.D. Razvitiye infrastruktury Kryma kak neotyemlemaya chast razvitiya ekonomiki gostinichnogo i turisticheskogo biznesa [Development of the Infrastructure of the Crimea as an Integral Part of the Hotel and Tourism Business Economy Development]. Strategiya ustoychivogo razvitiya regionov Rossii, 2015, no. 25, pp. 41-49.

Spisok proizvedennykh samoletov Superdzhet-100 [List of the "SSJ100" Airliners Produced]. URL: http://superjet.wikidot.com/wiki:produced (accessed 11 February 2021).

Trusevskaya A.S., Terekhina V.S. Tendentsii razvitiya turizma v Krymu [Trends in the Development of Tourism in Crimea]. Tvorchestvo i sovremennost, 2018, no. 1 (5), pp. 98-104.

Federalnoye agentstvo vozdushnogo transporta (Rosaviatsiya). Subsidirovaniye aviaperevozok [The Federal Agency for Air Transport (Rosaviatsiya). Subsidizing of Air Transportation]. URL: https://favt.gov.ru/dejatelnost-vozdushnyeperevozki-subsidirovanie/ (accessed 11 February 2021).

Federalnoye agentstvo vozdushnogo transporta. Rosaviatsiya. Perevozki passazhirov [The Federal Agency for Air Transport. Rosaviatsiya. Passenger Carriage]. URL: https://favt.gov.ru/ dejatelnost-vozdushnye-perevozki-perevozkipassazhirov/ (accessed 11 February 2021).

Federalnoye agentstvo vozdushnogo transporta (Rosaviatsiya). Subsidirovaniye aviaperevozok $v$ gorod Simferopol [The Federal Agency for Air Transport (Rosaviatsiya). Subsidizing of Air Transportation to Simferopol]. URL: https:// favt.gov.ru/dejatelnost-vozdushnye-perevozkisubsidirovanie-simferopol/ (accessed 11 February 2021).

Federalnuyu trassu "Tavrida» v Krymu polnostyu zakonchat v 2022 godu [The Federal Tavrida Highway in Crimea Will Be Fully Completed in 2022]. URL: https://tass.ru/info/5200479 (accessed 11 February 2021).

Federalnyy konstitutsionnyy zakon ot 21.03.2014 № 6-FKZ (red. ot 30.12.2020) «O prinyatii v Rossiyskuyu Federatsiyu Respubliki Krym i obrazovanii v sostave Rossiyskoy Federatsii novykh subyektov - Respubliki Krym i goroda federalnogo znacheniya Sevastopolya» [Federal Constitutional Law No. 6-FKZ of 21.03.2014 (as amended on 30.12.2020) "On the Admission of the Republic of Crimea to the Russian Federation and the Formation of New Subjects Within the Russian Federation - the Republic of Crimea and the Federal City of 
Sevastopol"]. Access from Reference Legal System "KonsultantPlyus".

Buta Airways Fleet Details and History. URL: https:// www.planespotters.net/airline/Buta-Airways (accessed 11 January 2021).

Cagliari Airport. Destinazioni. URL: http://www. sogaer.it/it (accessed 11 February 2021).
Planespotters. Fly Arystan. URL: https://www. planespotters.net/airline/FlyArystan (accessed 11 January 2021).

Resultats D'activite des Aeroports Francais - 2019. Statistiques de Traffic. UAF \& FRA (Union des Aeroports Francais \& Francophones Associes), 2020. $105 \mathrm{p}$.

\section{Information About the Authors}

Vladimir V. Rublev, Postgraduate Student, Department of Entrepreneurship and Logistics, Plekhanov Russian University of Economics, Stremyanny Lane, 28, Bld. 1, Off. 116-117, 117997 Moscow, Russian Federation, v.v.rublev@yandex.ru, https://orcid.org/0000-0002-5673-6573

Oleg N. Larin, Doctor of Sciences (Engineering), Professor, Department of Entrepreneurship and Logistics, Plekhanov Russian University of Economics, Academician of the Russian and International Academies of Transport, Stremyanny Lane, 28, Bld. 1, Off. 116-117, 117997 Moscow Russian Federation; Professor, Department of Logistics Transport Systems and Technologies, Russian University of Transport, Obraztsova St, 9, Bld. 9, 127994, GSP-4 Moscow, Russian Federation, larin_on@mail.ru, https://orcid.org/ 0000-0001-9020-2228

\section{Информация об авторах}

Владимир Владимирович Рублев, аспирант кафедры предпринимательства и логистики, Российский экономический университет им. Г.В. Плеханова, Стремянный переулок, 28, корпус 1, каб. 116117, 117997 г. Москва, Российская Федерация, v.v.rublev@yandex.ru, https://orcid.org/0000-0002-5673-6573

Олег Николаевич Ларин, доктор технических наук, профессор кафедры предпринимательства и логистики, Российский экономический университет им. Г.В. Плеханова, Стремянный переулок, 28, корпус 1, каб. 116-117, 117997 г. Москва, Российская Федерация; профессор кафедры логистических транспортных систем и технологий, Российский университет транспорта, ул. Образцова, 9, стр. 9, 127994, ГСП-4 г. Москва, Российская Федерация, larin_on@mail.ru, https://orcid.org/0000-0001-9020-2228 